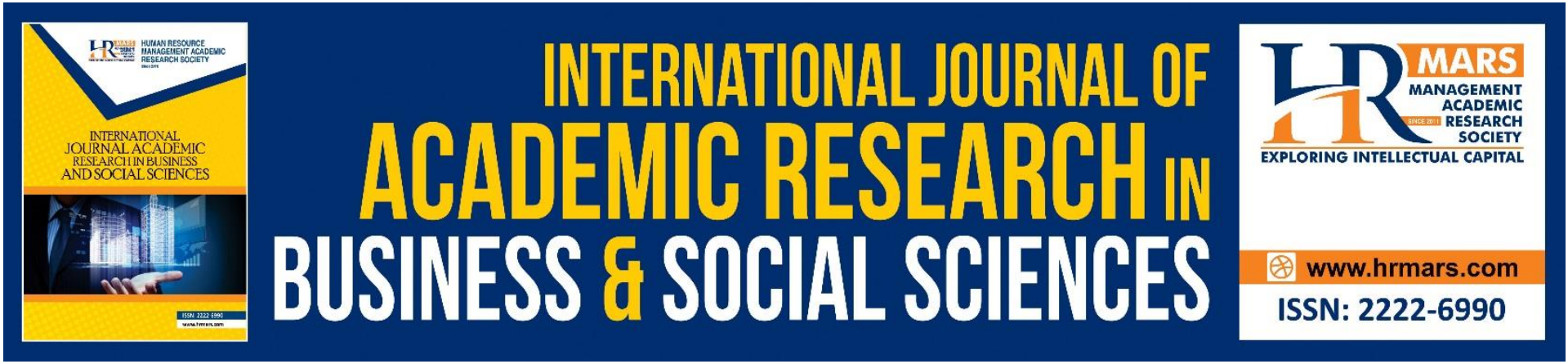

\title{
Higher Order Thinking Skills and Collaborative Learning Approach among Secondary School Students
}

\author{
Daud, M.Y, M. J. A Rahman \& Ensimau, N. K
}

To Link this Article: http://dx.doi.org/10.6007/IJARBSS/v9-i11/6716

DOI: 10.6007/IJARBSS/v9-i11/6716

Received: 15 October 2019, Revised: 25 October 2019, Accepted: 02 November 2019

Published Online: 24 November 2019

In-Text Citation: (Daud, Rahman, \& Ensimau, 2019)

To Cite this Article: Daud, M. Y., Rahman, M. J. A., \& Ensimau, N. K. (2019). Higher Order Thinking Skills and Collaborative Learning Approach among Secondary School Students. International Journal of Academic Research in Business and Social Sciences, 9(11), 1520-1528.

\section{Copyright: (C) 2019 The Author(s)}

Published by Human Resource Management Academic Research Society (www.hrmars.com) This article is published under the Creative Commons Attribution (CC BY 4.0) license. Anyone may reproduce, distribute, translate and create derivative works of this article (for both commercial and non-commercial purposes), subject to full attribution to the original publication and authors. The full terms of this license may be seen

at: http://creativecommons.org/licences/by/4.0/legalcode

Vol. 9, No. 11, 2019, Pg. 1520 - 1528

\section{Higher Order Thinking Skills and Collaborative Learning Approach among Secondary School Students}




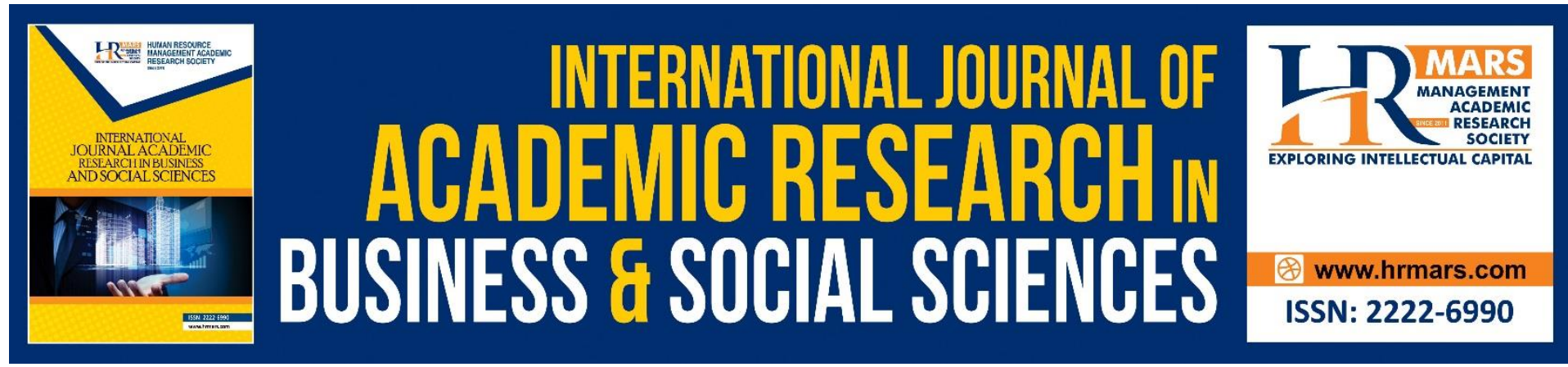

Daud, M.Y, M. J. A Rahman \& Ensimau, N. K

Faculty of Education, National University of Malaysia (UKM), Bangi, Selangor, Malaysia

Abstract: Although higher order thinking skills (HOTs) have been introduced in schools to assists students to apply knowledge, skills and values in solving problems, current data from PISA and TIMMS showed that the level of HOTs among school students in Malaysia is low. This study aimed to identify the level of HOTs among secondary school after the implementation of collaborative learning approach. The study employed an action research study design and involved 70 students who have been divided into collaborative learning and conventional learning classes. The data was analysed using descriptive statistics with the aids of SPSS program. Results showed that students in the collaborative learning class attain higher HOTs in comparison to students in the conventional learning class. The study indicated that collaborative learning approach helps students to acquire and apply HOTs across Mathematic subjects. This study further indicated that teachers' training programs should expose teacher trainees to theoretical and practical aspects of collaborative learning to reinforce the implementation of the learning approach in schools worldview.

Keyword: Collaborative Learning, Higher Order Thinking Skills, Mathematics, Secondary Schools, Malaysia.

\section{Introduction}

Education system in Malaysia continuously strengthen the potential of individuals in a holistic way as a means to develop capable and balanced human capital as aspired by the National Education Philosophy. Accordingly, teaching and learning activities are planned in such a way to produce students that would contribute to the development of the country (Ministry of Education Malaysia, 2013). For example, the Malaysian Education Blueprints 2013-2015 outlined six generic skills, i.e., leadership skills, bilingual skills, ethics and spirituality, national identity, knowledge and critical thinking skills that students should acquire in schools (Ministry of Education Malaysia, 2013). Furthermore, the government has introduced a new curriculum for primary and secondary schools, namely Integrated Curriculum for Primary School (KBSR) and Integrated Curriculum for Secondary School (KBSM) in 1994 that would assist the development of holistic students. In particular, elements of critical and creative thinking skills (CCTS) have been introduced and embedded across various subjects in schools (Ministry of Education Malaysia, 2014b). Later, Standard Curriculum for Primary School (KSSR) in 2011 and Standard Curriculum for Secondary School (KSSM) in 2016 produced by Ministry of Education Malaysia (2016a) and Ministry of Education (2016b) have been introduced in national schools to further reinforce thinking skills among students via the implementation of students' assessments and evaluations that focused on problem solving.

\section{Literature Review}

Although Malaysia has access to comprehensive education, but there are some shortcomings in measuring the level of achievement of higher order thinking skills (HOTS) among students. According 
to the Ministry of Education Malaysia (2014a), HOTS is defined as the ability to apply knowledge, skills and values to make reasoning and reflection to solve problems, make decisions, innovate and strive to create something (Rosli \& Maarof, 2017; Ghani, Zakaria \& Rahman, 2016; Ministry of Education Malaysia 2014a). To cope with the increasing global competition in an economic environment driven by innovation and creativity, the government emphasized students to acquire and master HOTs (Khalid, 2017). The application of HOTS comprised of main elements of curriculum, assessment and Pedagogy, and support elements of curriculum, community and private support, and resources and development (Abdullah, Embi \& Nordin, 2011). On the other hand, Trends in International Mathematics and Science Study (TIMMS) and the Programme for International Student Assessment (PISA) are identified as two internationally recognized assessment that measure the level of mastery of HOTS among school students. TIMMS is an assessment that assesses the level of mastery in Science and Mathematics, while the PISA assessment is intended to evaluate the efficiency of a 15 years old students in the context of reading, mathematics and science. Data from the TIMSS and PISA showed that school students in Malaysia were left behind students in her neighbouring countries such as Singapore and Vietnam in HOTs. For example, the performance of 15-years-old students in Singapore, South Korea and Hong Kong is three years ahead of 15-year-old students in Malaysia (OECD, 2013). On the other hand, PISA results showed that Malaysia ranked $57^{\text {th }}$ out of 74 participating countries. As TIMSS and PISA results have been perceived as among indicators of quality of education system in the era of globalization (Mubarak \& Razak, 2017; Zamir \& Faizli, 2013), the result have raised concern on the quality of Malaysian education system particularly in preparing future generation that would be able to solve problems.

There are several factors that contribute to Malaysia's performance in TIMSS and PISA tests. Firstly, TIMSS and PISA questions employed unstructured questions that require students to interpret, reflect and evaluate information or existing knowledge based on a real life situation. On the contrary, examination-oriented learning system in Malaysia requires teachers to complete syllabus on time in order to prepare students for examinations. Accordingly, teaching and learning process in schools often conducted quickly, and using exercise books or workbooks, memorizing and asking common questions to train students for their examination (Ministry of Education Malaysia, 2014c). Although the strategies are useful to train students for the examination, such process often ignore the process of students developing conceptual understanding of topics that they had studied. Secondly, TIMSS and PISA studies used random sampling that involved high and low performing students. Such selection would create gap between the groups and lower the overall students' score. Thirdly, although central national examination such as UPSR, PMR and SPM contained HOTs item, their ratio was smaller compare to TIMSS and PISA tests. In this respect, TIMMS and PISA test results were often relatively lower compared to central national examination results such as PMR and SPM results.

Although HOTs has become national education agenda, previous studies (e.g., Ministry of Higher Education, 2013; Phang, Ming \& Nambiar, 2015) indicated that most school teachers do not apply HOTs in their teaching and learning process and relying on traditional teaching strategies that train students to answer examination question. Therefore, as an attempt to increase students' acquisition of HOTs, this study aimed to increase students' acquisition and application of HOTs in the context of Mathematics.

\section{Method}

The study employed an action research study to identify the level of HOTs among form two students after and before conventional and collaborative learning approaches were implemented. The study 
involved 74 form two students from two classes who attained almost similar levels of HOTs who divided in equal number into conventional and collaborative learning classes. Students in the classes were given a pre-test before and post-test after the classes were conducted for one week. The pretest and post-test contained similar items related to HOTs focusing on word procedural and were developed based on national Mathematics syllabus for form two secondary schools. Items contained in the pre-test and post-test are shown in Table 1. Later, teachers who taught the classes would score students' answer sheets using a prepared scoring scheme.

Table 1: Items on pre-test and post test

\begin{tabular}{|c|c|}
\hline No & Question with Sentence \\
\hline 1 & $\begin{array}{l}\text { The ratio of male to female students at SMK Bukit Tajam is 3:5. If the } \\
\text { number of students in the school is 1840, find the number of female } \\
\text { students. }\end{array}$ \\
\hline 2 & $\begin{array}{l}\text { The ratio of oranges to apples in a fruit stall is } 7: 2 \text {. If the difference } \\
\text { between the two types is } 180 \text {, find the sum of the two types. }\end{array}$ \\
\hline 3 & $\begin{array}{l}\text { The cost of the } 8 \mathrm{~m} \text { wire is } R M 12.40 \text {. What is the cost of the same } 22 \mathrm{~m} \\
\text { wire? }\end{array}$ \\
\hline 4 & $\begin{array}{l}\text { A sum of money is shared between Ali and Kamal in a ratio of 4:3. Ali } \\
\text { received RM280 more than Kamal. How much money received by } \\
\text { Kamal? }\end{array}$ \\
\hline 5 & $\begin{array}{l}\text { The ratio of Arni to Badariah's age is 3:8. The difference between them } \\
\text { is } 20 \text { years. Calculate the age of Arni. }\end{array}$ \\
\hline 6 & $\begin{array}{l}\text { The perimeter of a rectangle is } 84 \mathrm{~cm} \text {. The ratio of width to length is } \\
5: 9 \text {. Calculate the width and length of the rectangle. }\end{array}$ \\
\hline 7 & $\begin{array}{l}\text { The ratio of the square of the area } A \text { to the area of the square of } B \text { is } \\
\text { 9:4. Given the length of the side of the square } A \text { is } 6 \mathrm{~cm} \text {, find the length } \\
\text { of the side of the square } B \text {. }\end{array}$ \\
\hline 8 & $\begin{array}{l}\text { Eight trees can be saved if } 500 \mathrm{~kg} \text { is recycled. How many trees can be } \\
\text { saved if } 2500 \mathrm{~kg} \text { of paper is recycled? How much paper mass can be } \\
\text { recycled if } 200 \text { trees are saved? }\end{array}$ \\
\hline 9 & $\begin{array}{l}\text { For every RM50 that Siti receives from her father, she will give her } \\
\text { sister RM8. If Siti gave her sister RM24, how much money did she } \\
\text { receive from her father? }\end{array}$ \\
\hline 10 & $\begin{array}{l}\text { Justin is } 4 \text { years older than Daniel. Justin's age ratio to Daniel is 7:5. } \\
\text { What is Justin's age ratio to Daniel six years later? }\end{array}$ \\
\hline
\end{tabular}

\section{Results}

This section discusses respondents' profile and pre-test and post-test results for collaborative learning and conventional learning classes. As illustrated in Table 2, the respondents were composed of $37 \%$ of male and $63 \%$ of female of form two students in a rural school in Malaysia. The majority of the students were Malay (85\%), and followed by Iban (7\%), Bidayuh (4\%), Chinese (1\%) and Orang Ulu (3\%). 


\begin{tabular}{ccc}
\hline Demographics & Item & No (\%) \\
\hline \multirow{2}{*}{ Gender } & Male & $28(37 \%)$ \\
& Female & $46(63 \%)$ \\
\hline \multirow{3}{*}{ Ethnic } & Malay & $63(85 \%)$ \\
& Iban & $5(7 \%)$ \\
& Bidayuh & $3(1 \%)$ \\
& Cina & $1(3 \%)$ \\
& Orang Ulu & $2(3 \%)$ \\
\hline
\end{tabular}

Table 3 shows pre-test test result for collaborative learning and conventional learning classes. As illustrated in Table 3, there were three HOTs items in the conventional learning class that scored at moderate level, while there were seven HOTs items scored at low level. The results were almost similar for the collaborative learning class. There were two HOTs items scored at moderate level in the collaborative learning class, while there were eight HOTs items scored at low level. On the average, Table 3 indicated that students' level of HOTs IN both conventional and collaborative learning classes were quite low as students in the conventional and collaborative learning classes attained score mean of HOTS at 1.98 and 2.116 respectively.

Table 3: Pre-test Results for Conventional and Collaborative Learning Classes

\begin{tabular}{|c|c|c|c|c|c|c|}
\hline \multirow[b]{2}{*}{ Item } & \multicolumn{3}{|c|}{$\begin{array}{l}\text { Conventional Learning Class (37 } \\
\text { respondents) }\end{array}$} & \multicolumn{3}{|c|}{$\begin{array}{c}\text { Collaborative Learning Class ( } 37 \\
\text { respondents) }\end{array}$} \\
\hline & Mean & $\begin{array}{l}\text { Standard } \\
\text { Deviation }\end{array}$ & $\begin{array}{c}\text { Mean } \\
\text { Score level }\end{array}$ & Mean & $\begin{array}{l}\text { Standard } \\
\text { Deviation }\end{array}$ & $\begin{array}{c}\text { Mean } \\
\text { Score } \\
\text { level }\end{array}$ \\
\hline 1 & 2.33 & 0.745 & Low & 2.13 & 0.732 & Low \\
\hline 2 & 2.90 & 0.566 & Moderate & 1.89 & 0.612 & Low \\
\hline 3 & 1.04 & 0.768 & Low & 1.74 & 0.724 & Low \\
\hline 4 & 2.32 & 0.832 & Low & 2.02 & 0.865 & Low \\
\hline 5 & 1.15 & 0.811 & Low & 1.99 & 0.798 & Low \\
\hline 6 & 1.89 & 0.636 & Low & 2.52 & 0.632 & $\begin{array}{l}\text { Modera } \\
\text { te }\end{array}$ \\
\hline 7 & 1.50 & 0.558 & Low & 1.76 & 0.593 & Low \\
\hline 8 & 2.01 & 0.642 & Low & 2.89 & 0.687 & $\begin{array}{l}\text { Modera } \\
\text { te }\end{array}$ \\
\hline 9 & 2.35 & 0.695 & Moderate & 2.14 & 0.668 & Low \\
\hline 10 & 2.32 & 0.899 & Moderate & 2.08 & 0.863 & Low \\
\hline $\begin{array}{l}\text { Total } \\
\text { Mean }\end{array}$ & 1.981 & & Low & 2.116 & & Low \\
\hline
\end{tabular}

Table 3: Mean and Standard Deviation for Pre Test

Table 4 showed pre-test results for convetional and collaborative learning classes. As indicated in Table 4, there were two HOTs items in the conventional learning class scored at highest level, while there were eight HOTs items scoced at moderate level. On the other hand, there were seven HOTs items scored at highest level, while there were three HOTs items scored at moderate level. The data showed that HOTs' acquisition have increased among students in the collaborative learning class with HOTs 
score mean increased to 3.75 in comparison to students in conventional learning class who attained HOTs score mean of only 3.05 .

\section{Discussion}

The findings support previous studies such as by Laal \& Ghodsi (2012) who suggested that a collaborative learning approach is a useful learning approach because it enables students to cooperatively analyze, synthesize and evaluate ideas. Additionally, interaction between members of the same group and between different groups in collaborative learning help students to learn and experience certain skills and knowledge together. For example students would explain their answers to their friends and the justification of doing so. Accordingly, opinions expressed by all parties are important elements to develop the best answer.

Table 4: Post-test Results for Conventional and Collaborative Learning Classes

\begin{tabular}{ccccccc}
\hline & \multicolumn{2}{c}{$\begin{array}{c}\text { Conventional Learning Class (37 } \\
\text { respondents) }\end{array}$} & \multicolumn{3}{c}{$\begin{array}{c}\text { Collaborative Learning Class (37 } \\
\text { respondents) }\end{array}$} \\
\cline { 2 - 7 } Item & Mean & $\begin{array}{c}\text { Standard } \\
\text { Deviation }\end{array}$ & $\begin{array}{c}\text { Mean } \\
\text { Score } \\
\text { Level }\end{array}$ & $\begin{array}{c}\text { Mean } \\
\text { rd } \\
\text { Deviati } \\
\text { on }\end{array}$ & $\begin{array}{c}\text { Mean Score } \\
\text { Level }\end{array}$ \\
\hline 1 & 2.57 & 0.736 & Moderate & 2.97 & 0.728 & Moderate \\
2 & 3.12 & 0.689 & Moderate & 3.78 & 0.629 & High \\
3 & 2.35 & 0.987 & Moderate & 4.10 & 0.897 & High \\
4 & 3.65 & 0.678 & Moderate & 3.92 & 0.738 & High \\
5 & 3.05 & 0.975 & Moderate & 4.05 & 0.954 & High \\
6 & 2.76 & 0.895 & Moderate & 3.81 & 0.787 & High \\
7 & 2.37 & 0.685 & Moderate & 3.52 & 0.983 & Moderate \\
8 & 3.15 & 0.642 & Moderate & 3.77 & 0.745 & High \\
9 & 3.80 & 0.684 & High & 3.88 & 0.892 & High \\
10 & 3.67 & 0.931 & High & 3.69 & 0.674 & Moderate \\
\hline Total & & 3.05 & Moderate & 3.75 & High \\
mean & & & & & & \\
\hline
\end{tabular}

Collaborative learning approach also promotes responsive teaching culture that would contribute toward positive learning experiences in the classrooms. Responsive teaching culture enhances a student's social, academic and cultural levels (Liu et al., 2014) as teachers respond positively to diverse students in their classrooms. By establishing cultural cohesion in the classroom, teachers promote respect for cultural diversity among students and create a condusive environment for students to learn and excel in their learning. Responsive classroom learning cultures could benefit from the use of a specific tool in collaborative learning approach known as scaffolding. Teachers and peers would support students to complete task that could not be completed on their own. According to Yen \& Shalili (2015); Anastasiadou \& Griva, (2018) such collaborative efforts increases students' selfconfidence, self-esteem and faith in their own culture and experience. In this context responsive and collaborative classroom learning cultures encourages students to make use their own culture in order to illustrate a concept or information that may be helpful to the process, and thus create a more 
meaningful learning process and outcomes. Later, when students are able to handle tasks on their own, teachers would provide more challenging tasks to students until students' learning outcomes are attained.

Collaborative learning approach has a positive impact on students' achievementas because teachers shift from traditional teaching to innovative learning strategies. However, to ensure the success of collaborative learning approach, all learning stakeholders need to participate and collaborate directly and indirectly in the implementation of the learning approach (Sarmila, Zaimah \& Lyndon, 2018; Shah \& Hussin, 2013; Samail, Zaidi, Mohamed, Kamaruzaman, 2018). More than a theoretical exposure, the efforts must be supported by a conducive learning environment. This includes teaching and learning time schedules for the implementation of collaborative learning approach, and physical and digital support equipments. Finally, willingness and involvement of schoollevel leadership, the District Education Office and the State Education Department are also contributing factors to the successful implementation of collaborative learning approach in any educational institutions.

In addition to collaborative learning approach, Ismail (2018) suggested that classroom infrastructure such as conducive learning space, latest and sufficient information technology tools contribute to students' mastery of HOTs. Teachers and students should play their respective roles. According to Lasan, Noh \& Hamzah (2017), The success and effectiveness of educational institutions in developing HOTs among students depends largely on the ability of teachers to implement the teaching and learning process that supports HOTs. For example Hassan et al. (2017) stated that the lack of coherence between current and previous lessons distract students' applcation of HOTs such as analyzing, synthesizing and evaluating information during learning process. Moreover, Yusoff \& Ahmad (2014) and KPM (2014b) suggested that that co-curriculum is another element that could be used to cultivate HOTs among students.

\section{Conclusion}

This study aimed to identify students' level of HOTs after collaborative learning approach was implemented in form two Mathematic subject. The findings showed that students' level of HOTs in a collaborative learning class is higher than a convention learning class. The study suggested that collaborative learning could improve students' acquision of HOTs in Mathematic subjects. Accordingly, teacher training programs must expose teacher trainees to conceptual and pratical aspects of collaborative learning approach while Ministry of Education provides training programs for Mathematic teachers to implement collaborative learning approach. The findings indicated that future research should examine the effectiveness of collaborative learning approach in comparison to other learning approaches via quasi experiment research design. Future studies also should apply collaborative learning approach to increase the level of HOTs across other subjects such as Geography, History, languages and others.

\section{Acknowledgement}

This work was supported by UKM [Grant GG-2019-018]

\section{References}

Ghani, A. A., Zakaria, E. \& Rahman, S. ( 2016). The impact of using visualisation technique towards 
mathematics problem solving involving hots question. Proceedings of International Conference on Mathematics and Science Education, Universitas Pendidikan Indonesia, Bandung: West Jawa, Indonesia. Pp 53-59

Abdullah, A., Embi, M. A., \& Nordin, N. (2011). The Role of Students in the Development of a Collaborative Learning Community through Networked Learning: A Malaysian Perspective. International Journal of Learning. 18(1). Pp 347-360

Hassan, M. R., Mustapha, R., Yusuff, N. K. N., \& Mansor, R. (2017). Pembangunan Modul Kemahiran Berfikir Aras Tinggi Di Dalam Mata Pelajaran Sains Sekolah Rendah: Analisis Keperluan Guru. Sains Humanika.

Ismail, R. A. R. (2018). Aplikasi Konsep "4C" Pembelajaran Abad Ke-21 dalam Kalangan Guru Pelatih Pengajian Agama Institut Pendidikan Guru Kampus Dato' Razali Ismail. Asian People Journal, 1. Pp 45-65.

Ministry of Education Malaysia. (2014a). Kemahiran berfikir aras tinggi (KBAT): Aplikasi di sekolah (Higher Order Thinking Skills: Application in Schools). Putrajaya: Bahagian Pembangunan Kurikulum, KPM.

Ministry of Education Malaysia. (2014b). Elemen KBAT dalam ko-kurikulum (Elements of HOTs in Cocurriculum). Putrajaya: Bahagian Pembangunan Kurikulum, KPM.

Ministry of Education Malaysia. (2014c). Elemen KBAT Pedagogi (HOTs Elements in Pedagogy). Putrajaya: Bahagian Pembangunan Kurikulum, KPM

Ministry of Education Malaysia. (2016a). Buku Penerangan Kurikulum Standard Sekolah Rendah (KSSR) (Books of Primary School Curriculum Standards). Putrajaya: Bahagian Pembangunan Kurikulum, KPM.

Ministry of Education Malaysia. (2016b). Buku Penerangan Kurikulum Standard Sekolah Menengah (KSSM) (Books of Secondary School Curriculum Standards). Putrajaya: Bahagian Pembangunan Kurikulum, KPM.

Khalid, F. (2017). Understanding university students use of facebook for collaborative learning International Journal of Information and Education Technology, 7(8). Pp 595-600

Laal, M., \& Ghodsi, S. A. (2012). Benefits of Collaborative Learning. Procedia Social and Behavioral Sciences. 31 (2012). Pp 486-490

Lasan, T. R. T., Noh, C. M. A., \& Hamzah, M. I. (2017). Pengetahuan, Sikap dan kesediaan pelajar terhadap kemahiran berfikir aras tinggi (KBAT) dalam mata pelajaran Tasawwur Islam. Tinta Artikulasi Membina Ummah, 3(1); Pp 15-28

Liu, O. P., Selvadurai, S., Hoon, O. P., \& Najib, M. A. A. M. (2014). Education for social cohesion: promoting cultural literacy through school curriculum, The Ninth International Malaysian Studies Conference (MSC9), 18-20 August.

Rosli, M. F. M. \& Maarof, N. ( 2017). The effects of Higher Order Thinking Skills (HOTS) questions in improving esl pupils' writing performance. The 5th Global Summit on Education. Pp 70-80

Ministry of Education. (2013). Malaysia Education Blueprint 2013-2025: Preschool to Post Secondary School. Putrajaya: Ministry of Education.

Mubarak, A. A., \& Razak, N. R. (2017). Malaysian students' achievement in TIMSS 2011: Does Science inquiry really matter?. Malaysian Journal of Learning and Instruction (MJLI), Special issue on Graduate Students Research on Education. Pp 1-25.

Yusoff, Y. M., \& Ahmad, N. H. (2014). Penglibatan Aktiviti Ko-Kurikulum dari Persepsi Pelajar di Kolej Hulu Langat. Available from https://www.academia.edu/8766534/

OECD. (2013). PISA 2012 Results: ( 2012).What Makes Schools Successful? Resources, Policies and Practices (Volume IV), PISA , OECD Publishing. Available from 
http://dx.doi.org/10.1787/9789264201156-en.

Phang, L. M., Ming, T. S. \& Nambiar, R. M. K. (2015). Matching teaching styles and learning styles: what happens in the case of a mismatch?. Journal Social Sciences and Humanities, (1), 66-76

Sarmila, M. S., Zaimah, R., \& Lyndon, N. (2018). Corporate social responsibility collaborative strategies for local communities. International Journal of Engineering \& Technology. 7 (2). Pp 596-601

Shah, S. M. H., \& Hussin, S. (2013). Collaborative Managerial Practices of Heads of Educational Institutions: Principals' and Students Perspective. Jurnal Pendidikan Malaysia. 38 (2): Pp 3340.

Yen, T. S. \& Shalili, S. H. (2015). Effective Teaching of Higher Order Thinking (HOT) in Education. The Online Journal of Distance Education and e-Learning 3(2).

Zamir, Z. F., \& Faizli, A. A. (2013). Analisis laporan TIMSS 2011 dan pencapaian Malaysia.

Samail, N. A. B., Zaidi, N. S. B., Mohamed, A. S. B., Kamaruzaman, M. N. B. (2018). Determinants of Financial Performance of Islamic Banking in Malaysia, International Journal of Academic Research in Accounting, Finance and Management Sciences 8 (4): 21-29

Anastasiadou, A., \& Griva, E. (2018). Identifying Teachers' Views on the Impact of Early Foreign Language Learning on Children's Linguistic Development. 2Multilingual Academic Journal of Education and Social Sciences, 6(1), 21-40. 